\title{
Preparation and characterization of silica hydrogel nanocomposites as a drug delivery system
}

\author{
Noha M. Abdelazeem ${ }^{1,}$ *, El-Sayed M. El-Sayed ${ }^{2}$, Sherief M. Abo-Naf ${ }^{3}$, Hosnia M. Abu- \\ Zeid $^{1}$, Gamal A. Meligi ${ }^{4}$ \\ ${ }^{1}$ Physics Department, Faculty of Women for Arts; Science and Education, Ain Shams University, Cairo, \\ Egypt. \\ ${ }^{2}$ Physics Department, Biophysics Branch, Faculty of Science, Ain Shams University, Cairo, Egypt. \\ ${ }^{3}$ Glass Research Department, National Research Centre (NRC), El-Buhouth Str., Dokki, 12622 Cairo, \\ Egypt. \\ ${ }^{4}$ Chemistry Department, Faculty of Science, Ain Shams University, Cairo, Egypt.
}

\begin{abstract}
:
Nowadays, the bacterial resistant infection risks to antibiotics have the limelight of developing new and natural antibacterial biomaterials. So, this work aimed to prepare drug carriers for Ceftriaxone (CFX) loading based on hydrogel nanocomposites for increasing the CFX loading capacity and improving the antibacterial properties of the hydrogels. Hence, a novel nanocomposites based on Ca-alginate hydrogels were prepared as antibacterial model. The morphology, textural, and the molecular interaction between the Mesoporous silica nanoparticles (MSNs) and the hydrogels were evaluated by using SEM, DCS, and FT-IR characterization techniques and loading efficiency was calculated. The loading efficiencies of (0, 5, $10 \%$ MSNs) loaded with CFX were 2.379, 19.597 and $16.05 \%$, respectively. Furthermore, the antibacterial property of the hydrogels was tested by using colony forming test at three different loaded CFX concentrations. The results showed that, as MSNs \% was increased in the alginate matrix, the loading CFX concentration increased. Thus, at $10 \% \mathrm{MSNs}$ of $425.6 \mu \mathrm{g} / \mathrm{ml} \mathrm{CFX}$ showed a significant viability \% with $\left(\mathrm{p}^{* *}<0.01\right)$ that was reached to $15.473 \% \pm 0.399$ relative to negative control. So, the hydrogels were to be used as a good CFX drug carrier and demonstrated a bactericidal effect against gram positive and gram negative bacteria.
\end{abstract}

Keywords: Antibacterial, CFX, hydrogels, MSNs, nanocomposites

\section{Introduction}

Recently, acute and chronic wounds were always the main medical problems which produced massive amounts of exudates which has adversely affect healing [1, 2]. All microorganisms are growing in all chronic wounds, so the clinical consequences were appeared

*Corresponding author: Noha M. Abdelazeem, Physics Department, Faculty of Women for Arts; Science and Education, Ain Shams University, Cairo, Egypt.

E-mail: noha.mustafa@women.asu.edu.eg 
as infectious or sepsis systemically. Hence, the chronic wounds ideal therapy nowadays involves reduction of the infectious bacteria and management of the exudate amounts for the wounds [3, 4]. Moreover, the topical and systemic antibiotic bacterial resistance was increasing due to overuse and misuse [5]. Therefore, several approaches have been developed to improve the antibiotic treatments including formulation of available antibiotics or producing new antimicrobial agents. Nanomaterials have a special advantage to a drug formulation as a function of antimicrobial agents [6,7]. The therapeutic effects were increased for several antibiotics by targeted delivery to the infectious site, blood circulation extension and controlled release that decreased the side effects via minimizing the required dose [8]. Ceftriaxone Sodium has a great effect against a broad spectrum of microorganisms, but it formulated for parenteral not orally approach, due to its lower permeability and stability in the acidic media of the stomach environment. CFX has a longer plasma half-life, about 4 to 10 times than other antibiotics in this class of cephalosporin which even more effective against gram-negative microorganisms than gram-positive bacteria [9]. It was recommended that using CFX once daily due to its long half-life bioavailability in plasma. Thus, CFX has higher activity against aerobic gram-negative bacteria than first and second-generation cephalosporin, but less than the earlier cephalosporin generations within many gram-positive bacteria [10]. However, Alginate biopolymer was a linear polysaccharide extracted from the brown algae composed of two saccharides pimeric $\beta$-d-mannuronate $(M)$ and $\alpha$-l-guluronate $(G)[11,12] . M$ and $G$ blocks are covalently bonded through 1-4-glycosidic linkages and arranged into either homopolymeric blocks (MM and GG) or alternating blocks (MG MG) along the polymeric backbone [13]. Alginate hydrogel was formed by presence of divalent cations such as $\mathrm{Ca}^{2+}$ during crosslinking process forming egg-box structure, which have been used as a drug carriers and bioactive food additive. The gate keeper biopolymer such as sodium alginate (SA) was found in a surface of MSNs bestows a unique properties of organic and inorganic components for nanocomposites construction [14]. So, our goal in this work is preparing the silica based alginate hydrogel nanocomposites to increase the CFX loading concentrations onto MSNs and improve the bactericidal effect of the CFX loaded alginate carriers against gram-positive and gram-negative bacteria. 


\section{Experimental}

\subsection{Preparation of Mesoporous silica nanoparticles}

Briefly, 0.2 g Cetyltrimethyl ammonium bromide (CTAB) was dissolved into mixed solution of $44 \mathrm{ml}$ deionized water and anhydrous ethanol under $800 \mathrm{rpm}$ vigorous stirring at $25^{\circ} \mathrm{C}$ room temperature. Then, $0.4 \mathrm{ml}$ ammonia was added until $\mathrm{pH}$ was 9.9 with keep stirring. $0.3 \mathrm{ml}$ Tetraethyl Orthosilicate (TEOS) was added dropwise to the homogenous solution under vigorous stirring overnight at $25{ }^{\circ} \mathrm{C}$. The solution was washed three times with ethanol/water, ultracentrifugation at $10000 \mathrm{rpm}$, dried at $80^{\circ} \mathrm{C}$ and finally calcined at $520{ }^{\circ} \mathrm{C}$ for $2 \mathrm{~h}[15,16]$.

\subsection{Preparation of hydrogel nanocomposites}

The carboxylate anions of Sodium Alginate (SA) solution were cross-linked with $0.1 \mathrm{M}$ $\mathrm{Ca}^{++}$, resulting the gel formation produced. Briefly, mixed MSNs with SA solution at different concentrations of $0,5,10 \%$ related to SA concentration followed by cross-linking with $\mathrm{Ca}^{++}$ions [17]. After that, dispersed MSNs in CFX solution (1:1) at final concentration $10 \mathrm{mg} / \mathrm{ml}$, shaking for $6 \mathrm{~h}$ in dark, ultracentrifugation at $10000 \mathrm{rpm}$ then washing with ethanol/water three times. Mixed with $2 \%$ SA solution with keep stirring until reach to homogenous solution and crosslinking with $0.1 \mathrm{M} \mathrm{Ca}^{++}$ions, washing and finally dried at $25^{\circ} \mathrm{C} \mathrm{RT}$.

\subsection{Characterization techniques}

\subsubsection{Dynamic light scattering measurements}

A Zetasizer Nano-ZS equipped with 633 nm laser (Malvern Instruments Ltd, UK) was used to determine particle size and $\zeta$-potential based upon dynamic light scattering (DLS). According to the Stokes-Einstein equation, the hydrodynamic particle diameter X_h (particle core + adsorbate/ligand shell) was calculated. The weighted hydrodynamic particle size distribution was converted to a number \% via Mie correction through the size-dependent extinction coefficient [18].

\subsubsection{Transmission Electron Microscope}

The mesostructured of MSNs was studied by TEM instrument Philips CM200, Mahwah, NJ, USA. The sample was dispersed in ethanol before examination and deposited on carbon coated grids. 


\section{Fourier Transform Infra-red spectroscopy}

Fourier transform infrared spectrophotometer (FTIR, Bruker Alpha П, Platinum AT, UK) was used for studying the chemical structure of all samples. FT-IR spectrum was recorded by scanning mode within range of $4000-400 \mathrm{~cm}^{-1}$.

\subsubsection{Differential Scanning Calorimetry}

The thermal property of hydrogel nanocomposites was investigated by the differential scanning calorimeter (DSC). The measurements were carried out with Setaram Themys HP in a pan $\mathrm{Al}$ pierced led in the $\mathrm{N}_{2}$ atmosphere at a heating rate of 0.01 to $100{ }^{\circ} \mathrm{C} / \mathrm{min}$.

\subsubsection{Scanning Electron Microscope}

The surface morphology was performed on the hydrogel nanocomposite samples using the FEG Quanta 250 FEG-SEM, which was equipped with Schottky field emission gun and Everhart-Thornley detector for secondary electrons to deliver a high resolution of $1.2 \mathrm{~nm}$ and $20 \mathrm{kV}$, backscattered electron detector in high vacuum mode and large field secondary detector for low vacuum operation $3.0 \mathrm{~nm}$ and $20 \mathrm{kV}$ imaging.

\subsection{Drug loading experiment}

The loading and encapsulation efficiencies were calculated by dispersed MSNs with different concentrations of $(0,5,10 \%)$ in which (CFX: MSNs 1:1, 1:2) at final desired concentration of CFX at $10 \mathrm{mg} / \mathrm{ml}$, keep them shaking overnight at RT in dark. Then centrifugation at $5000 \mathrm{rpm}$ on Sigma Laborzentrifugen $\mathrm{GmbH}$ apparatus (Germany). The supernatant was analyzed using UV/Vis (Cary 5000 UV-Vis-NIR spectrophotometer, Varian, Australia) spectrophotometer at $240 \mathrm{~nm}$. The drug loading efficiency was calculated according to equation (1), in which NPs weight was initial weight of MSNs, and the encapsulation efficiency also was calculated according to equation (2) [19].

$$
\begin{gathered}
\text { Drug Loading }(\%)=\frac{\text { Weight of the CFX drug }}{\text { NPs weight }} \times 100 \\
\text { Encapsulation Efficiency }(\%)=\frac{\text { CFX encapsulated amount }}{\text { Total CFX added }} \times 100
\end{gathered}
$$

\subsection{Antibacterial activity test}

The antibacterial effect of CFX loaded Ca-Alginate nanocomposite hydrogels was studied by using colony forming unit test, using bacterial resistant strains of E. coli and $S$. 
aureus. Dried hydrogels (150 mg) were suspended in $1 \mathrm{ml}$ bacterial cultures of $10^{4} \mathrm{CFU} / \mathrm{ml}$ for both bacterial types E. coli and S. aureus. The prepared hydrogels were incubated for $24 \mathrm{~h}$ in shaking incubator at $37 \pm 0.1^{\circ} \mathrm{C}$. The bacterial cultures without the samples were considered as a negative control. Then, withdrawal a loopful of the bacterial cultures and cultivated on the Muller Hinton agar (MHA) in a petri dish. The agar plates were incubated for $24 \mathrm{~h}$ and the bacterial colonies number was counted, which indicated the number of survival cells in the suspension. The colony-forming unit (CFU) was counted, the cell viability relative to negative control for each group was calculated according to equation (2).

$$
\% \text { of Viability relative to control }=\boldsymbol{C F U _ { \text { treated } }} / \boldsymbol{C F U _ { \text { Control } }}
$$

\subsection{Statistical Analysis}

All experiments were performed in triplicate. Cell Viability \% is expressed as the mean \pm (SD), and the significance was calculated by paired t-test using (IBM SPSS Statistics, Version 25.0. Armonk, NY: IBM Corp.), where values of $\mathrm{p}<0.05$ were considered statistically significant.

\section{Results and Discussion}

\subsection{Dynamic light scattering measurements.}

Mesoporous silica nanoparticles and ceftriaxone loaded MSNs have particle size distribution ranged from 30 to $712 \mathrm{~nm}$ for MSNs and from 190 to $531 \mathrm{~nm}$ CFX loaded MSNs. In which MSNs were dispersed in deionized water by dynamic light scattering measurements. The average mean diameter was $136.6 \pm 23.4 \mathrm{~nm}$ and $272.7 \pm 19.5 \mathrm{~nm}$ for MSNs and MSNs-CFX (MSNs: CFX 1:1), respectively, as shown in Fig 1. (a \& b). 

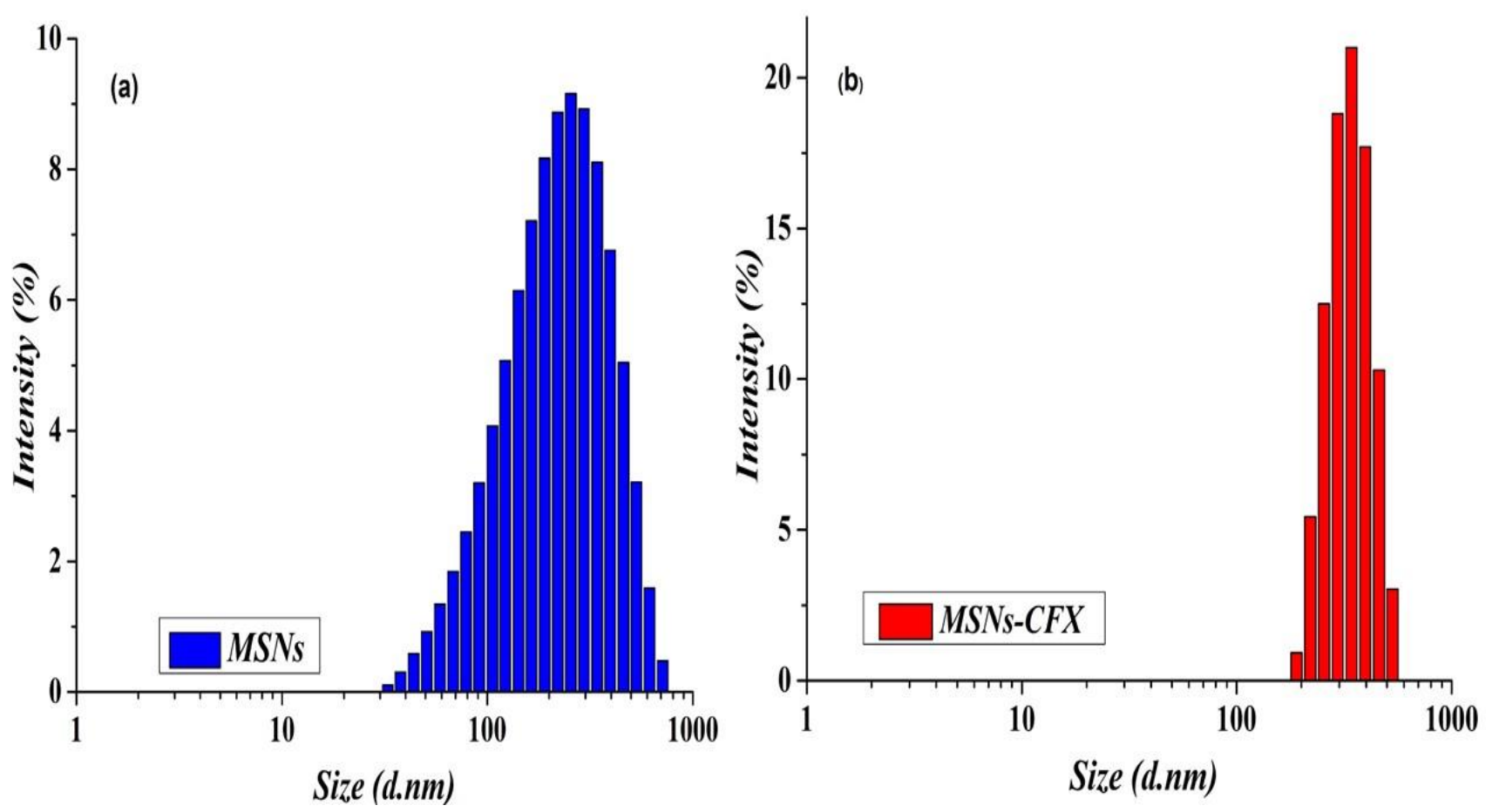

Fig 1. DLS measurements of MSNs and MSNs-CFX

\subsection{Transmission Electron Microscope (TEM)}

Mesoporous silica nanoparticles were prepared by modified Stöber method [21]. TEM micrographs were performed to study the morphological and textural properties of the MSNs. Fig 2. (a-d) micrographs confirm that all MSNs have spherical morphology with relatively smooth surfaces and narrow size distribution. The highly ordered mesostructured with an average size was approximately $58.2 \pm 6.3 \mathrm{~nm}$ with good dispersity at different magnifications of 100000x and 120000x. 

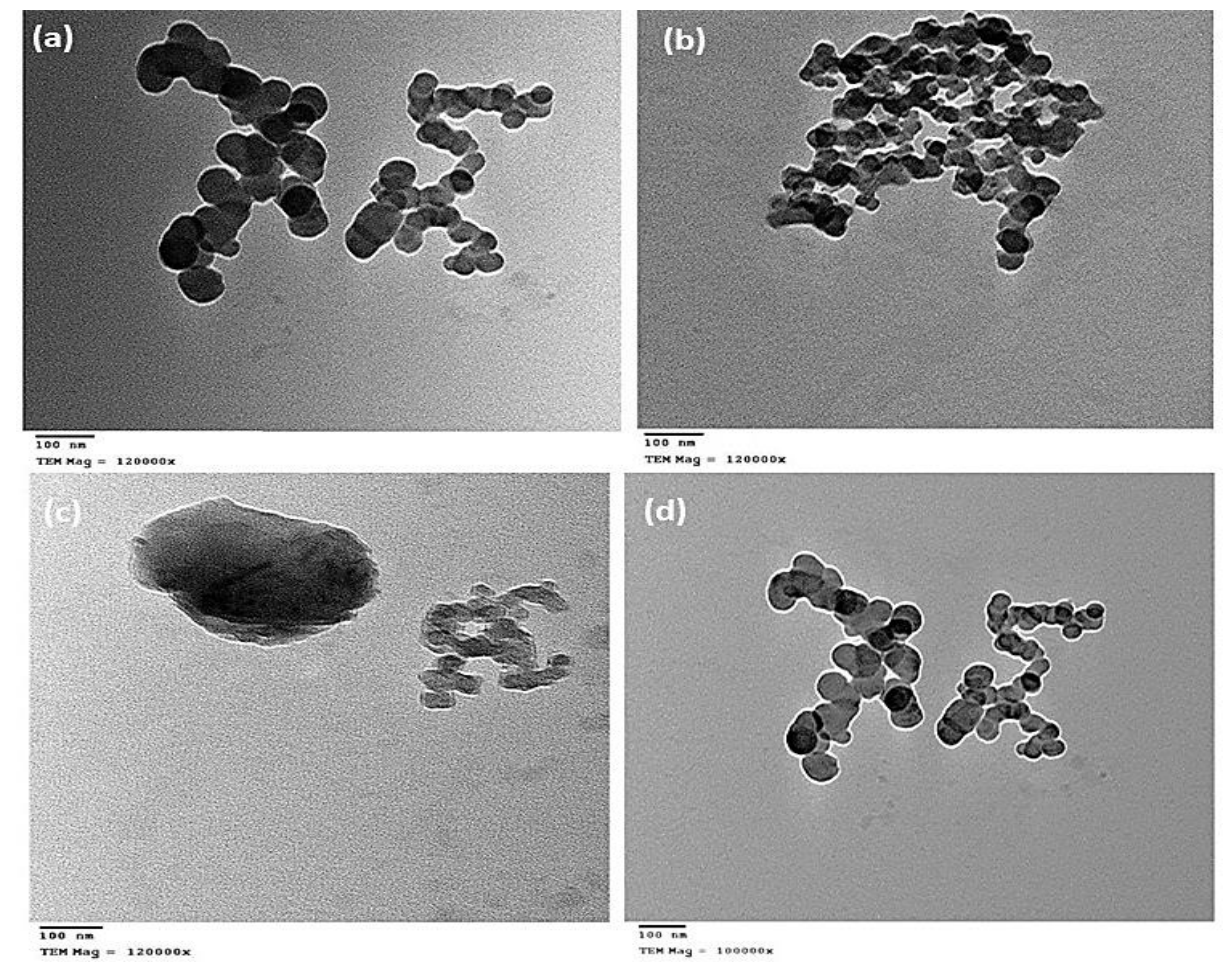

Fig 2. TEM of MSNs with different magnifications of 100000x and 120000x at scale bar

\section{$100 \mathrm{~nm}$.}

\subsection{Fourier transform Infra-red spectroscopy}

FT-IR spectra was used to explore the changes of the chemical bond in pure SA and Alginate hydrogel nanocomposites. Fig 3. (a) showed the hydroxyl bond was located at 3304 $\mathrm{cm}^{-1}$ of alginate and asymmetric and symmetric vibrations of carbonyl groups were positioned at $1594,1402.94 \mathrm{~cm}^{-1}$, respectively [22, 23]. After crosslinking with calcium ions, the carbonyl bands have shifted to 1613 and $1425 \mathrm{~cm}^{-1}$, respectively. This is attributed to calcium cations replaced sodium ions forming egg-box structure (b) [24]. Furthermore, the peaks present at 1081 and $1025 \mathrm{~cm}^{-1}$ of (v $\boldsymbol{C}-\boldsymbol{O}-\boldsymbol{C}$ ) of glycosidic linkage have no band shift, this proved the crosslinking process [25]. After loading CFX, the band getting broader which located at 3399 $\mathrm{cm}^{-1}$ due to overlapping of hydroxyl stretching vibration and amide group of CFX. New peak appeared at $1760 \mathrm{~cm}^{-1}$ due to $\beta$-lactam ( $\boldsymbol{C}=\boldsymbol{O}$ ) of CFX (c). The two strong bands of amide N$\mathrm{H}$ deformation of CFX and (vas $\boldsymbol{C}=\boldsymbol{O}$ ) are located in the same wavenumber at $1601 \mathrm{Cm}^{-1}$. This confirmed that CFX was successfully loaded in the nanocomposites. 


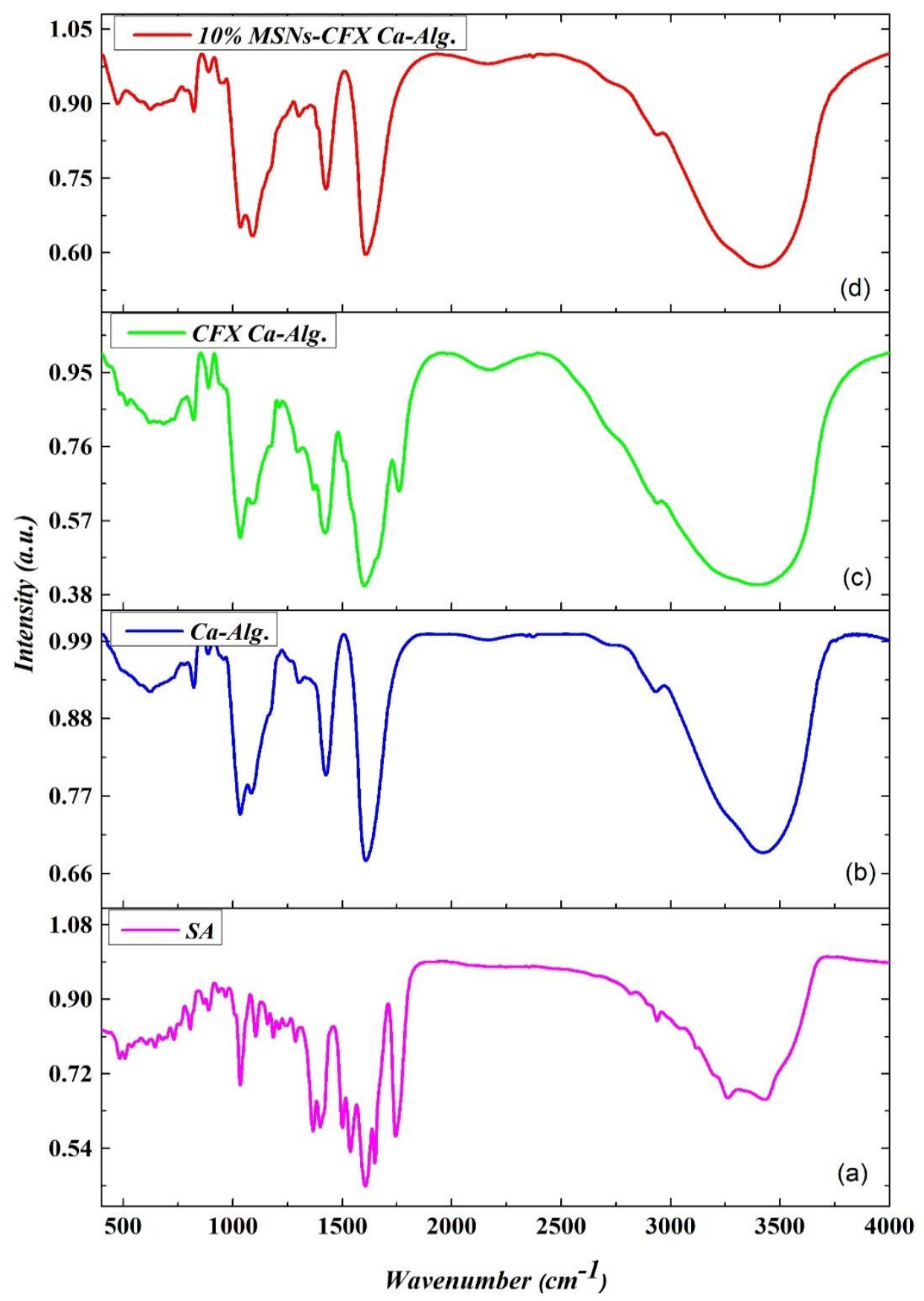

Fig 3. FT-IR spectra of (a) pure SA (b) Ca-Alg. (c) CFX loaded Ca-Alg. (d) $10 \%$ MSNsCFX Ca-Alg., (MSNs: CFX 2:1).

\subsection{Differential Scanning Calorimetry (DSC)}

DSC technique was used to study the physical nature of polymer crystallinity, oxidation reactions and chemical changes. The chemical and physical changes were determined such as melting temperature Tm, crystallization temperature Tc and glass transition temperature $\mathrm{Tg}$. The DSC analysis was performed for SA polysaccharide and CFX loaded MSNs nanocomposites to study the effect of both chemical modification and MSNs-CFX percentage on the alginate properties. Fig 4 displayed DSC curve of alginate with an endothermic peak at 
$87^{\circ} \mathrm{C}$ attributed to water loss and an exothermic peak at $243{ }^{\circ} \mathrm{C}$ which indicate the biopolymer breakdown [26]. This exothermic peak was disappeared due to the $\mathrm{Ca}^{2+}$ ions crosslinking which increased the thermal stability of the egg box structure as shown in CFX loaded MSNs Ca-alginate hydrogels nanocomposite curves [27]. After addition of MSNs-CFX (5, 10\%), the characteristic endothermic peak of CFX loaded Ca-alginate nanocomposites with melting points (Tm) at $194{ }^{\circ} \mathrm{C}$ showed shift appreciably to 202 and $208{ }^{\circ} \mathrm{C}$, respectively, due to increasing the interaction between the bioactive and encapsulation matrix, whether made up by CFX loaded MSNs.

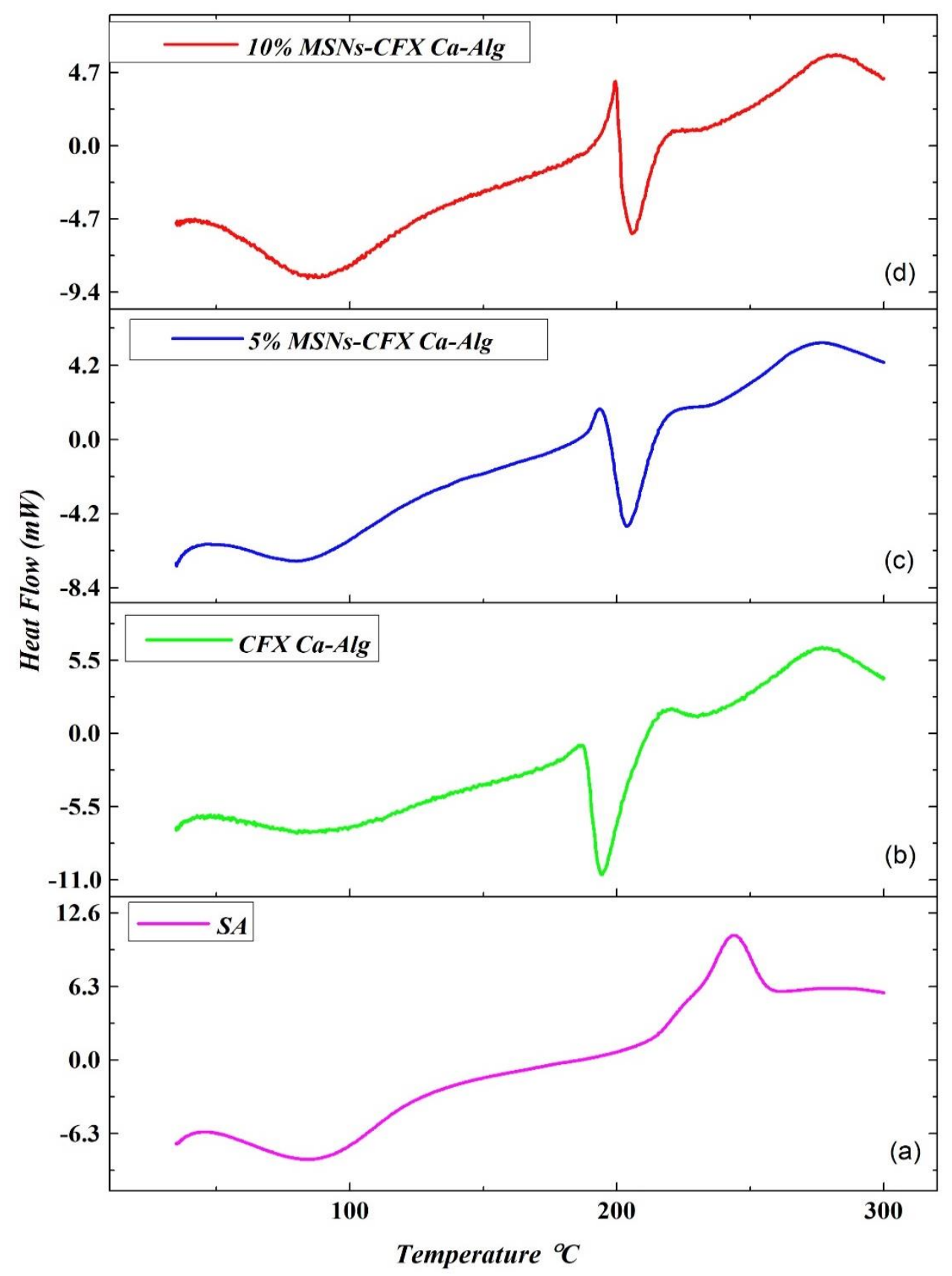


Fig 4. DSC thermograms of (a) pure SA (b) CFX loaded Ca-Alg. nanocomposites (c) 5\% MSNs-CFX Ca-Alg. nanocomposites (d) 10\% MSNs-CFX Ca-Alg. nanocomposites.

\subsection{Scanning Electron Microscope (SEM)}

The morphology of the Alginate nanocomposite surfaces was investigated by SEM at different magnifications. The hydrogel surface was multilayers come together to give the alginate network to support the radial gel formation during therapy as shown in Fig. 5. The internal structure of the hydrogels was a hollow with soft texture and denser compared to the external surface due to air drying process as in Fig. 5 (a \& b) [28]. After loading the CFX onto Ca-alginate hydrogels, the hydrogel surface was rough and sandy form with large crumbles area attributed to the crystalline nature of the CFX drug as shown in Fig. 5 (c \& d) at 6000X and 12000X magnifications, red arrows indicated the crystalline CFX entrapped at the hydrogel surface as shown in Fig. 5 (e). Moreover, the porous network of the polymer was increased after addition the MSNs-CFX which producing large channels due to water removal during the air drying process [29]. The alginate encapsulation enhanced the MSNs-CFX stability with CFX release retention. So the highly wrinkled area was due to the more densely cross-linked structure like the fibrous structure as shown in Fig. 5 ( $\mathrm{f} \& \mathrm{~g}$ ) at different magnifications 10000X and 12000X. Yellow arrow indicate the homogenous distribution of MSNs-CFX onto the alginate matrix.
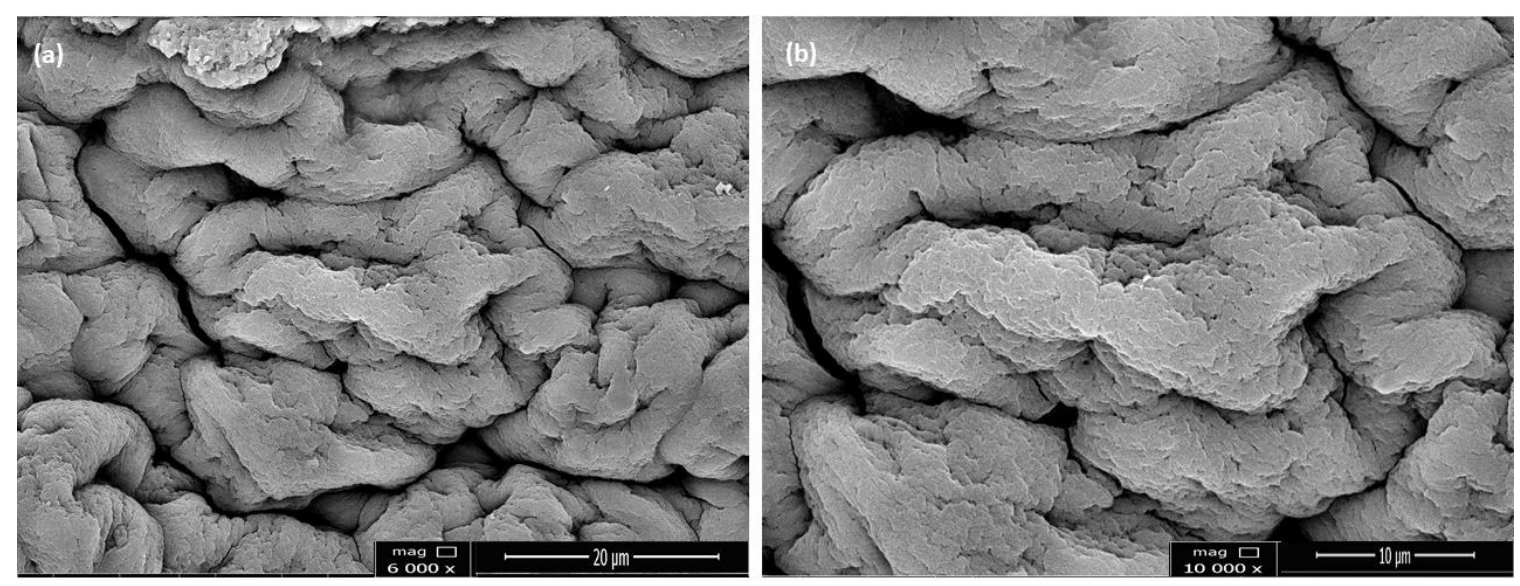

Fig 5. SEM micrographs of Ca-Alginate hydrogels at different magnifications (a) 6000X, (b) 10000X. 


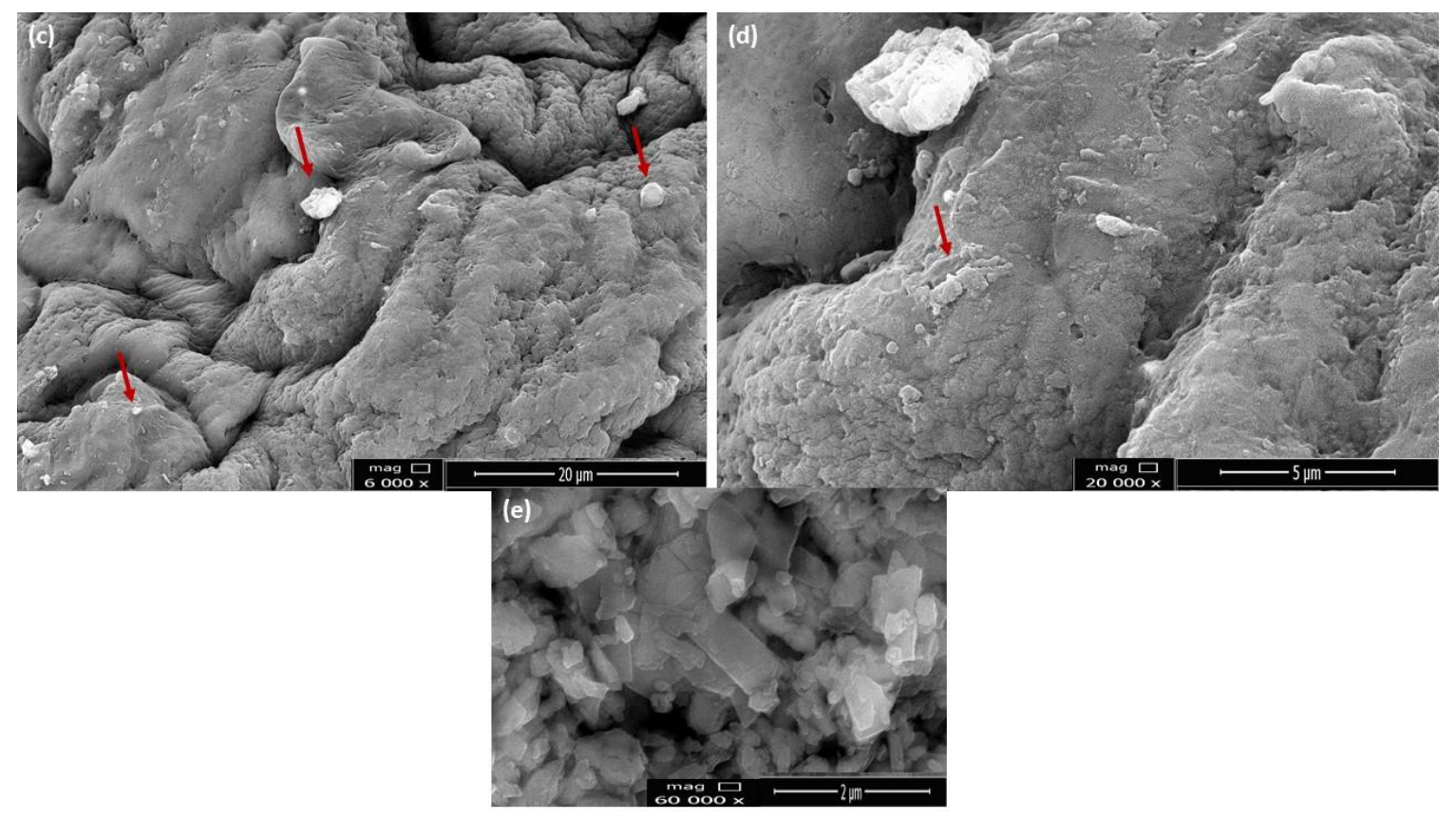

Fig 5. SEM micrographs of CFX loaded Ca-Alginate hydrogels at different magnifications (c) 6000X, (d) 20000X and (e) CFX crystalline structure at 60000X. Red arrows indicate CFX entrapment in Alginate matrix.
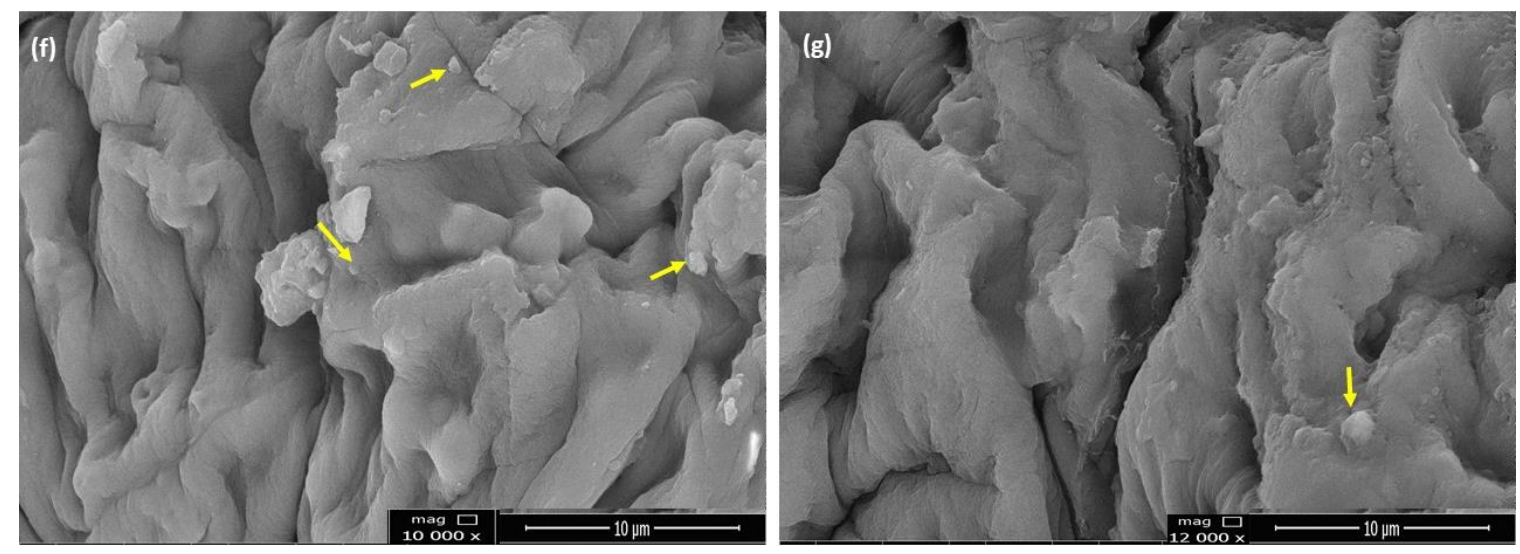

Fig 5. SEM micrographs of CFX loaded MSNs based Ca-Alginate hydrogels (10\% MSNs-CFX) at different magnifications (f) 10000X, (g) 12000X. Yellow arrows indicate well MSNs-CFX distribution in Alginate matrix.

\subsection{Drug loading experiment}

According to equation (1), the loading efficiency of ceftriaxone loaded Ca-alginate hydrogel (0\% MSNs) was $2.379 \%$, while the LE of ceftriaxone loaded MSNs (5\% MSNs) was increased to $19.5971 \%$ and decreased to $16.05 \%$ of $10 \%$ MSNs due to MSNs agglomeration during loading process. On the other hand, the encapsulation efficiencies were increased as 
$1.89,19.5,32.1 \%$ as MSNs concentration increased so the loading concentration increased according to previous equations $(1 \& 2)$.

\subsection{Antibacterial activity test}

Antibacterial properties were evaluated by colony forming counting test for CFX loaded Ca-alginate based MSNs hydrogel nanocomposites at different MSNs concentrations $(0,5,10 \%)$. At $0 \%$ MSNs the concentration of CFX which loaded onto Ca-alginate hydrogels was $237.9 \mu \mathrm{g} / \mathrm{ml}$, the viability decreased to $66.375 \% \pm 1.647$ after $24 \mathrm{~h}$ of incubation compared to negative control. Moreover, the viability $\%$ was saturated after $24 \mathrm{~h}$ incubation decreased to a $30.063 \% \pm 1.933$ for $5 \% \mathrm{MSNs}$ at $263 \mu \mathrm{g} / \mathrm{ml} \mathrm{CFX}$ as shown in table 1 . \& Fig 6 . As $10 \%$ MSNs, the viability \% was decreased to $15.473 \% \pm 0.399$ at $425.6 \mu \mathrm{g} / \mathrm{ml} \mathrm{CFX}$ which statistical significantly difference within 5\% MSNs-CFX and CFX loaded Ca-alginate hydrogels (0\% MSNs). This is due to bacterial DNA and polysaccharide chains were chelating with positively CFX antibiotic at optimized concentration $425.6 \mu \mathrm{g} / \mathrm{ml}$. The bacterial growth of S. aureus was higher than E. coli due to the cell wall of gram negative bacteria is thinner than that of gram positive bacteria [30]. The MSNs and alginate biopolymer used as both a reservoir and means for delaying the sustained drug release [31]. Hence, the stability of the alginate-based MSNsCFX nanocomposites was shown by the effect of the hydrogel carriers loaded with CFX drug for promising the viability results along with $24 \mathrm{~h}$ incubation and their ability to facilitate the CFX release onto the bacteria DNA and killing a large number of the bacterial cells without any degradation.

Table 1. Bacterial viability \% at different MSNs-CFX \% for both Gram-positive and Gramnegative bacteria.

\section{Ca-Alginate hydrogel}

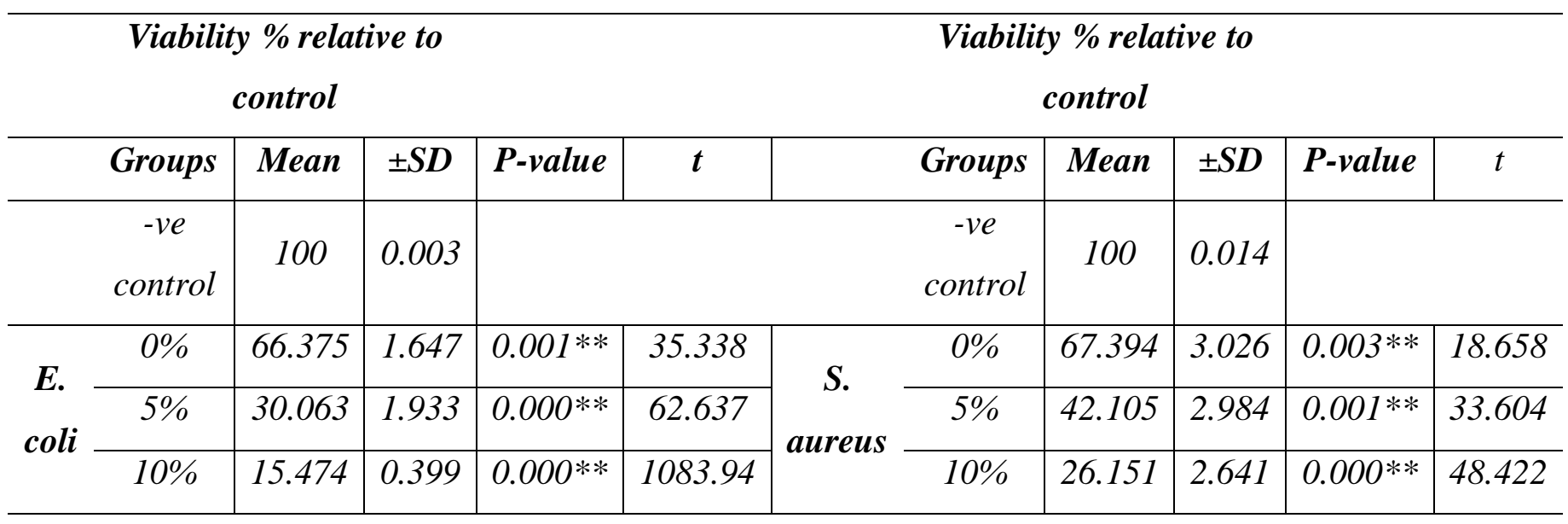


Viability \% was expressed as the mean $\pm(S D)$, and the significance where values of $p^{* *}<0.01$, where $p<0.05$ considered statistically significant, the viability \% was calculated according to equation (2) which mentioned previously. $t$ values in table 1 refer to test statistic for the paired Ttest.

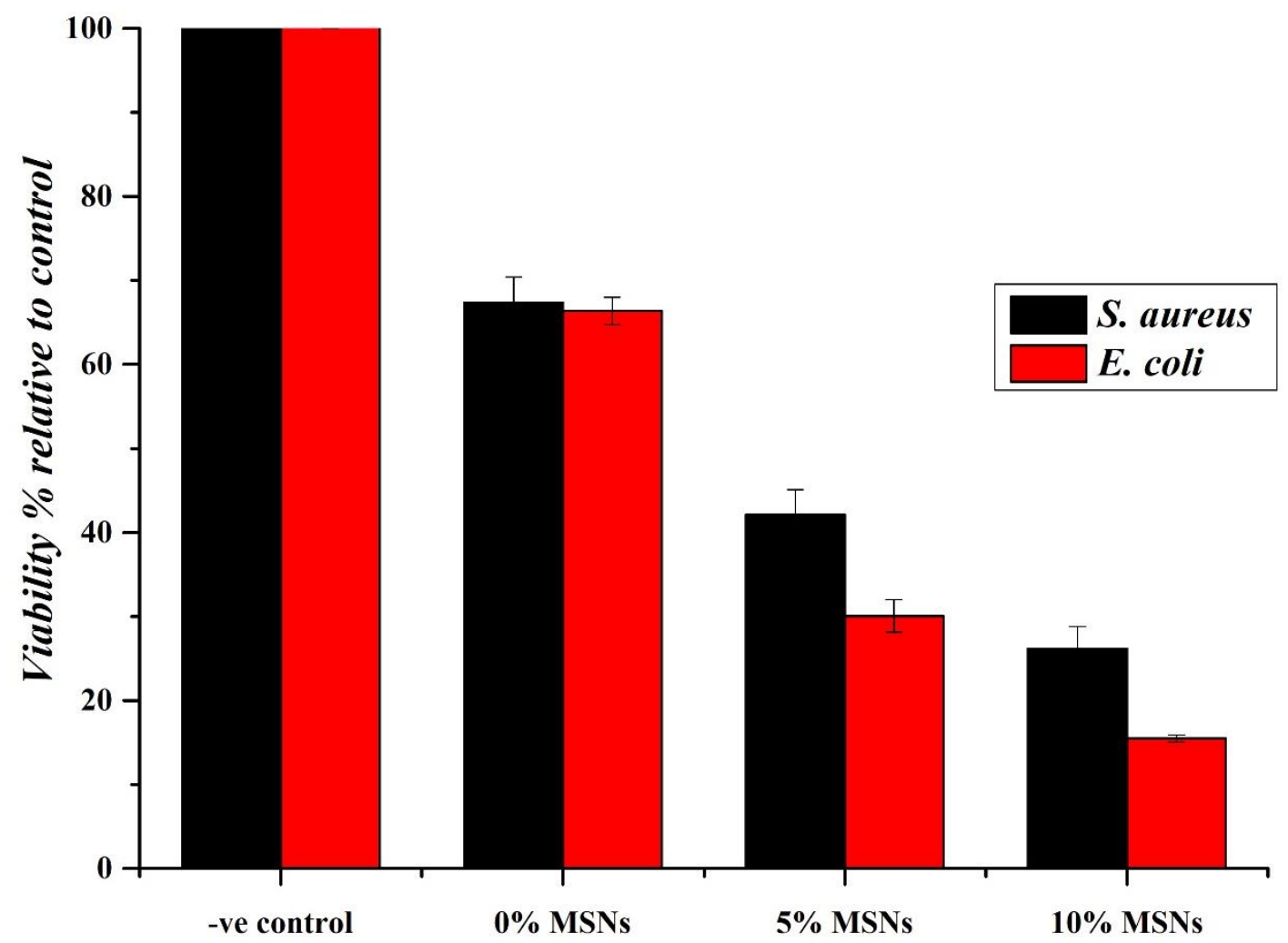

Fig 6. Bar chart of bacterial viability \% at different MSNs loaded CFX \% for both Gram-positive and Gram-negative bacteria.

\section{Conclusions}

In this work, the authors have developed a novel MSNs based alginate nanocomposite hydrogel as a drug carriers containing antibacterial CFX model drug. As a results, MSNs were a promising carriers due to its high loading capacity, large surface area and high efficiency. The results confirmed that, as MSNs concentrations mainly increased in the hydrogels, the CFX loading concentrations increase. Thus, the antibacterial efficiency of the hydrogel was improved due to the ceftriaxone local concentration increased at the bacterial cell receptors that permit the interaction with the antibiotic particles enabling efficient delivery of CFX to the molecular targets. The bacterial reduction of viable cells for CFX loaded hydrogel nanocomposites was higher for E. coli than S. aureus bacteria. 


\section{References}

[1] O. Andrea, I. Jancic, J. Vunduk, P. Petrovic, M. Milenkovic, B. Obradovic, "Achieving high antimicrobial activity: Composite alginate hydrogel beads releasing activated charcoal with an immobilized active agent," Carbohydrate polymers 196: (2018) 279-288.2.

[2] Z. Yin, Y. Qifeng, Z. Tong, C. Xiaoqiang, W. Zhengqi, Ni Zhang, S. Yundong, C. Yong, "Antibacterial activity and mechanism of green tea polysaccharide conjugates against Escherichia coli,". Industrial Crops and Products 152: (2020) 112464.

[3] L. Sanae, J. Uwingabiye, M. Frikh, L. Abdellatifi, J. Kasouati, A. Maleb, A. Bait, A. Lemnouer, M. Elouennass. "In vitro evaluation of the susceptibility of Acinetobacter baumannii isolates to antiseptics and disinfectants: comparison between clinical and environmental isolates," Antimicrobial Resistance \& Infection Control 6(1): (2017) 36.

[4] Z. Miao, Z. Xia, "Alginate hydrogel dressings for advanced wound management", International Journal of Biological Macromolecules 162: (2020) 14.

[5] L. David, P. Durani. "Topical antimicrobial therapy of chronic wounds healing by secondary intention using iodine products," International Wound Journal 5(2): (2008) 361368.

[6] N. Fredrik, Y. Zhang, J. PK Tan, K. Xu, H. Wang, C. Yang, S. Gao et al. "Biodegradable nanostructures with selective lysis of microbial membranes." Nature chemistry 3(5): (2011) 409-414.

[7] A. Zahra, G. Emtiazi, A. Zarrabi, "Novel synergistic activities of tetracycline copper oxide nanoparticles integrated into chitosan micro particles for delivery against multiple drug resistant strains: generation of reactive oxygen species (ROS) and cell death," Journal of drug delivery science and technology 44: (2018) 65-70.

[8] A. Nadia, P. Couvreur, "Nanocarriers for antibiotics: a promising solution to treat intracellular bacterial infections," International journal of antimicrobial agents 43(6): (2014) 485-496.

[9] M. Maria Luisa, D. Araújo Agarrayua, J. Carlosso Machado, C. Alberto Schmidt, "A fully validated microbiological assay to evaluate the potency of ceftriaxone sodium, " Brazilian Journal of Pharmaceutical Sciences 49(4): (2013) 753-762.

[10] da Trindade, M. Teixeira, H. Regina Nunes Salgado, "A critical review of analytical methods for determination of ceftriaxone sodium," Critical Reviews in Analytical Chemistry 48(2): (2018) 95-101.

[11] G. Cheong Hian, P. Wan Sia Heng, L. Wah Chan, "Alginates as a useful natural polymer for microencapsulation and therapeutic applications," Carbohydrate Polymers 88(1): (2012) $1-12$.

[12] G. Renmin, C. Li, S. Zhu, Y. Zhang, Y. Du, J. Jiang, "A novel pH-sensitive hydrogel based on dual cross-linked alginate/ $\mathrm{N}$ - $\alpha$-glutaric acid chitosan for oral delivery of protein," Carbohydrate polymers 85(4): (2011) 869-874. 
[13] V. Kokkarachedu, J. Tippabattini, K. Vimala, Claudio Toro, S. Emmanuel Rotimi, "Alginate-based composite materials for wound dressing application", A mini review, Carbohydrate Polymers 236: (2020) 116025.

[14] M. Xiaomei, R. Li, X. Zhao, Q. Ji, Y. Xing, J. Sunarso, Y. Xia, "Biopolymer composite fibres composed of calcium alginate reinforced with nanocrystalline cellulose," Composites Part A: Applied Science and Manufacturing 96: (2017)155-163.

[15] N. Valentina, S. Magnolia, M. Piludu, M. Nieddu, C. Antonio Caria, V. Sogos, M. ValletRegì, M. Monduzzi, A. Salis, "Mesoporous silica nanoparticles functionalized with hyaluronic acid. Effect of the biopolymer chain length on cell internalization," Colloids and Surfaces B: Biointerfaces 168: (2018) 50-59.

[16] B. Katharina, C. Martina Stürzel, J. Biskupek, U. Kaiser, F. Kirchhoff, M. Lindén, "Comparison of different cytotoxicity assays for in vitro evaluation of mesoporous silica nanoparticles," Toxicology in Vitro 52: (2018) 214-221.

[17] A. Calvo Tatiana, P. Santagapita, "Physicochemical characterization of alginate beads containing sugars and biopolymers," Journal of quality and reliability engineering 2016 (2016).

[18] Levin A. D., A. I. Nagaev, A. Yu Sadagov, "Determination of Number Density of Particles Together with Measurement of Their Sizes by Dynamic Light Scattering," Measurement Techniques 61(8): (2018) 760-76619.

[19] Y. Ning-ning, S. Li, G. Li, "Sodium alginate coated mesoporous silica for dual bioresponsive controlled drug delivery," Journal of Drug Delivery Science and Technology 46 (2018): 348-353.

[20] O. Jacob, A. Wirsén, Å. Norberg, J. Frie, G. Printz, H. Lagercrantz, G. H. Gudmundsson, B. Agerberth, B. Jonsson, "A novel cysteine-linked antibacterial surface coating significantly inhibits bacterial colonization of nasal silicone prongs in a phase one pre-clinical trial, " Materials Science and Engineering C 93: (2018) 782-789.

[21] S. Werner, A. Fink, E. Bohn, "Controlled growth of monodisperse silica spheres in the micron size range," Journal of colloid and interface science 26(1): (1968) 62-69.

[22] V. Wan-Ping, B. Beng Lee, A. Idris, A. Islam, B.Ti-Tey, E. Chan, "Production of ultrahigh concentration calcium alginate beads with prolonged dissolution profile," RSC Advances 5(46) : (2015) 36687-36695.

[23] Ru Feng, Lu Wang, Z. Peng, L. Zhen, Xiaoyu Li, G. Lili, "Development of the pH responsive chitosan-alginate based microgel for encapsulation of Jughans regia L. polyphenols under simulated gastrointestinal digestion in vitro," Carbohydrate Polymers 250: (2020) 116917.

[24] D. Annalnsa, B. A.Anna, L. Gaetano, G. Mario, d. Matteo, "Pharmaceutical applications of biocompatible polymer blends containing sodium alginate," Advances in Polymer Technology 31(3) : (2012) 219-230.

[25] H. Yan, D. Xiaoying, K. Lei, Z. Shangwen, Z. Dan, C. Han, X. Xincai, "Polysaccharides/mesoporous silica nanoparticles hybrid composite hydrogel beads for sustained drug delivery," Journal of Materials Science, 52(6): (2017) 3095-3109. 
[26] M. Tanja, C. Marzadori, D. Montecchio, C. Gessa, "Characterisation of Ca-and Alpectate gels by thermal analysis and FT-IR spectroscopy," Carbohydrate Research 340(16): (2005) 2510-2519.

[27] S. Olav, G. Skja., "Alginate as immobilization matrix for cells," Trends in biotechnology 8: (1990) 71-78.

[28] C. Bingchao, D. Li, Q. Huo, Q. Zhao, Q. Lan, M. Cui, W. Pan, X. Yang, "Two kinds of ketoprofen enteric gel beads (CA and CS-SA) using biopolymer alginate," asian journal of pharmaceutical sciences 13(2): (2018) 120-130.

[29] G. Reddy S., A. Saxena Pandit, "Effect of curing agent on sodium alginate blends using barium chloride as crosslinking agent and study of swelling, thermal, and morphological properties," International Journal of Polymeric Materials and Polymeric Biomaterials 62(14): (2013) 743-748.

[30] B. Sara, "Essential oils: their antibacterial properties and potential applications in foods - a review," International journal of food microbiology 94 (3): (2004) 223-253.

[31] J. Oju, Kang, K. Sun-Woong, L. Hee-Won, C. Ji Hyung, K. Byung-Soo, "Long-term and zero-order release of basic fibroblast growth factor from heparin-conjugated poly (L-lactideco-glycolide) nanospheres and fibrin gel," Biomaterials 27(8): (2006) 1598-1607. 


\section{الملخص بالعربية}

\section{تحضير وتوصيف متراكبات هيدرجيل السيليكا النانومترية كنظام لتوصيل الأدوية}

نهى مصطفى عبد العظيم1 - السيد محمود السيد سليمان2 - شريف محمد أحمد أبوناف3 ${ }^{2}$ - حسنية محمد أبوزيد1

$$
\text { - جمال عبد العزيز مليجي4 }
$$

1. ققسم الفيزياء - كلية البنات للأداب و العلوم و التربية - جامعة عين شمس - القاهرة - جمهورية مصر العربية.

2. قسم الفيزياء - شعبة الفيزياء الحيوية ـ كلية العلوم - جامعة عين شمس - القاهرة - جمهورية مصر العربية.

3. قسم بحوث الزجاج - المركز القومي للبحوث ـ شار ع البحوث ـ الدقي ـ ص ب 12622القاهرة - جمهورية

$$
\text { مصر العربية. }
$$

4. ققم الكيمياء - كلية العلوم - جامعة عين شمس - القاهرة - جمهورية مصر العربية.

في الوقت الحاضر، أصبحت مخاطر البكتيريا المقاومة للمضادات الحيوية تحت دائرة الضوء وذللك لتطوير مواد

حيوية جديدة ومواد حيوية طبيعية مضادة للبكتيريا. لذلك يَهُفف هذا العمل إلى إعداد ناقلات الأدوية لتحميل دواء

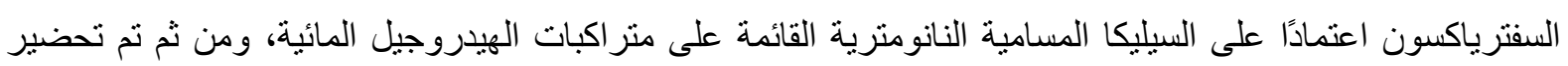
مثر اكبات نانومترية جديدة مُحملة بالسفترياكسون تعتمد على هيدروجيل ألجينات الكالسيوم كنموذج مضاد للبكتيريا. وقد أُجريت عليها بعض التوصيفات كدراسة السطح و الثكل والتفاعلات الجزيئية بين السيليكا النانومنرية و الهيدروجيل المائي بإستخدام تقنيات ماسح المجهر الضوئي SEM و التحليل الحراري DSC و FT-IR وتعيين كفاءة

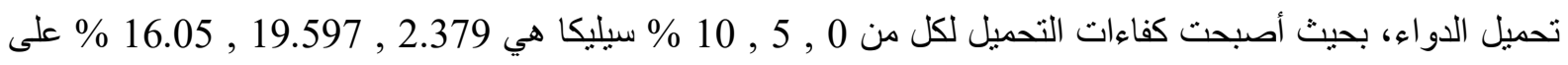
التو الي.

علاوة على ذلك فقد نم اختبار النشاط المضاد للبكتيريا للهيدروجيل المائي المُحمل بإستخدام اختبار Colony وذلك بإستخدام ثلاثة تركيز ات للسفترياكسون وقد أظهرت النتائج انه مع زيادة نسبة السيليكا تزداد قيمة التركيز المحمل الخاص بالسفتر ياكسون.

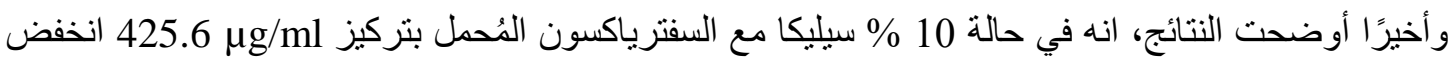

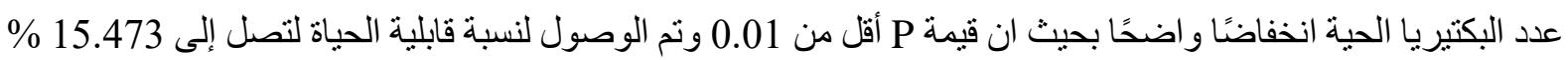

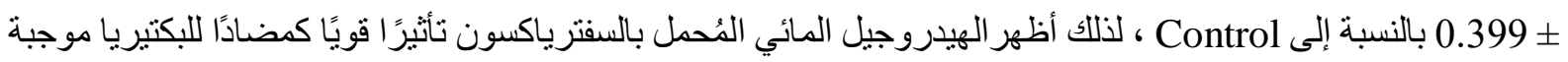

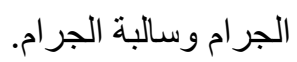

